DOI: $10.31866 / 2410-1915.21 .2020 .208239$

UDC 070.431(73):316.774(477)]:008

\title{
CULTURAL DIMENSION OF THE UKRAINIAN MEDIA SPACE IN INTERACTION WITH THE AMERICAN MODEL OF NEWS REPORTING
}

\section{Oleksii Krasnenko}

\author{
PhD student, \\ ORCID: 0000-0001-8398-8453, alexeykrasnenko@gmail.com, \\ Kyiv National University of Culture and Arts, \\ 36, Ye. Konovaltsia St., Kyiv, 01133, Ukraine
}

\section{For citations:}

Krasnenko, O. (2020). Cultural Dimension of the Ukrainian Media Space in Interaction with the American Model of News Reporting. Culture and Arts in the Modern World, 21, 90-104. https://doi. org/10.31866/2410-1915.21.2020.208239.

The purpose of the article is to determine the influence of American news reporting on the current state of the media space in Ukraine within the cultural aspect. The research methodology provides a cultural approach, which includes the analysis of changes in Ukrainian society and the transformation of news reporting. Reporter methods were used to perceive and interpret news and the journalist's news work. The analytical approach has helped to identify the influence of the American model of news reporting on the intellectual culture of Ukraine. The modelling method was applied for impact analysis of Ukrainian news reporting future model within the media space. Comparative analysis was used to compare American and Ukrainian models of news reporting. The scientific novelty is that for the first time, the cultural aspect of American model impact on the modern Ukrainian media space was studied and the future model of Ukrainian news reporting in the media space was predicted. Conclusions. It has been proven that with the project influence, media culture reaches a new level in cooperation with the media. Mass culture and postmodern media discourse have become attributes of contemporary Ukrainian culture. The entry of the news genre into a new phase of development allows us to qualify them as a subsystem that is the object of influence of the culture of society, and as its subject. At the same time, the media is a channel that influences cultural priorities and changes in the attitude of mind. And, the genesis of Ukrainian news reporting, as a subsystem of culture, has added new qualities that have signs of autonomy, secrecy and generalisation.

Keywords: mass media; media space; culture; cultural influence; information society; journalism; news reporting; American model.

\section{Introduction}

In the context of globalisation and the development of digital technologies, the intellectual culture of Ukrainian society is significantly influenced by the

(C) Oleksii Krasnenko, 2020

The article was received by the editorial office: 02.03 .2020 
media space, which becomes an essential factor in profound social and cultural changes in society. Journalism as a component of the media space is not a separate social institution but a part of media communication, media sphere. It causes a number of problems: the growth of information noise on the Internet, the decrease of trust in the media, media wars, the dominance of opinions over facts and the blurring of boundaries between evaluative comments and news. Two last problems are closely connected to the current state of news reporting, which is becoming an autonomous and aggressive subject of culture. One of the most famous models of news reporting in the world is the so-called American one. Thus, the relevance is determined by the influence of the latter on the media space as a component of Ukrainian culture in the modern world.

The cultural aspect of journalism, in particular, news reporting, has been studied by both national and foreign scholars. Among the foreign ones, we distinguish the research of the German philosopher and sociologist J. Habermas (2001), who, analysing the evolution of modern society, defined it as a society of contemporary type. The author claims that communication is a historical form that arises in culture and reflects its features. At the same time, the life-world cannot be interpreted in the categories of the system. In his turn, a leading English specialist in the field of media and communications, Professor D. McQuail (2013) emphasises that such concepts as mass media and mass communication are not synonyms since the former are organised technologies that enable mass communication, which can be used for personal, private or organisational purposes. And even though publishers can be independent, however, news in the USA is the agent of press systems for those who have concentrated political or economic power. Polish and English sociologist and philosopher Z. Bauman (2018), studying the cultural dimension of the modern world, described the state of humanity in it as a continuous movement, melting, overflow. In his opinion, now the beginning of a moving stage is taking place, in which a new reality is being built. A person becomes mobile and not burdened with long-term obligations. Everything that he creates, he can change. Thus, Russian researchers studied the peculiarities of medialisation of news and the influence of the mass media on various branches of modern cultural life. The attention of scientists was also focused on media texts, in particular, news ones. News texts are a complex multilevel and multidimensional phenomenon. They are classified into:

- the production method - collegial texts;

- functional and genre characteristics - genre-forming and those that implement one of the most important functions of the mass media - informative one (Zemlianova, 1999; Dobrosklonskaia, 2005).

National scholars D. Hallin and P. Manchini (2008) devoted their researches to the analysis of the modern model of American news reporting and the basic parameters and degrees on which this model is based. The well-known researcher and journalist H. Pocheptsov (2014) focused on the analysis of news in the cultural and social space of the USA and Ukraine. In his opinion, the most well-known method of managing mass consciousness through the media is the information agenda. It consists of keeping the necessary topics, events 
and interpretations in the information space. A reader/viewer is not interested in an event which is outside the 5-10 most discussed. That is why the authorities both in America and Ukraine are busy maintaining such an agenda that is important to them, suppressing the opposition one deliberately.

At the same time, the cultural aspect of the influence of the American model of news reporting on the modern Ukrainian media space has not been studied in national culturology thoroughly, which determines the importance of the chosen topic.

\section{Purpose of the article}

The purpose of the article is to determine the influence of American news reporting on the current state of the media space in Ukraine in the cultural aspect.

The research methodology consists in the use of the cultural approach, which includes the analysis of changes in Ukrainian society and the transformation of news reporting, which turns the latter into an autonomous and aggressive subject of culture. The reporter methods were used to perceive and interpret the news and news work of a journalist. The analytical approach helped to identify the influence of the American model of news reporting on the spiritual culture of Ukraine. The modelling method was applied to predict the future model of Ukrainian news reporting in the media space. The comparative analysis of media systems was used to compare American and Ukrainian models of news reporting.

\section{Main research material}

In Culture Studies, the study of news as a phenomenon which is crucial to information reality, two directions prevail: structural and semiotic and social and cultural approaches. According to the first, the news is considered "as language units of information and communication processes, varieties of texts, signs, codes, due to which real events are transposed to the level of conditional "mapping" of life facts" (Zemlianova, 1999, p. 143). According to the second, the news is studied as elements of social and cultural processes connected with the objective and historical regularities of development of society and civilisation as a whole. At the same time, the subject of news reporting is a piece of news as a unit of information flow.

In conditions when humanity begins to realise itself as a certain unity the population of the planet Earth - prompt information, accompanying globalisation, affects the interaction of different cultures directly. It is namely news reports that are the basic texts of mass media. In contrast, information and analytical texts are an extended version of the news, which differs in the mandatory presence of not only a report but also an analytical part - a commentary (Dobrosklonskaia, 2005, pp. 57-63). News is understood as journalistic texts, which are characterised by the transmission of the reported facts without evaluation and criticism. The purpose of news as information texts is to 
provide information that the recipient was not acquainted with, and which is not always perceived positively in the modern information society, but also out of consciousness - due to information overload. Not all information is useful for a person. A feature of news (information) journalism is also efficiency and impartiality. In journalism, a fact is defined as "any separate fragment of reality” (Mykhailyn, 2011, p. 116): an event, a phenomenon, statistical data, statements of a significant person, etc. At the same time, the difference between news TV journalism and a similar one on the radio or in the press is in the channel of information transmission. The emotional impact of broadcasting is much stronger, because a person perceives a significant amount of information through visual images. Thus, the personification of information is enhanced based on the non-verbal component of the air, a viewer trusts or does not trust the reports starting from the attitude to the journalist. Such specific features of TV broadcasting could not but affect its functional properties. In particular, M. Alieva notes the following functions of news TV journalism:

- information satisfaction function;

- cultural function (is realised through the appearance of the presenter and his manner of speech);

- audience consolidation function;

- recreational function;

- the function of ideological interpretation, etc. (Alieva, 2015, pp. 5-6).

We cannot agree with the definition of the latter function, but support the view of the Ukrainian researcher I. Mykhailyn (2011), who considered that "the task of news is not interpretation and regulation of reports" (p. 116). Thus, news reporting is a "certain pattern of news presentation" (Kvasnytsia, 2013, p. 33) as a standard of information journalism. We emphasise that the "news presentation" affects consciousness significantly and, in some way, forms the socio-culture of society.

Recently, TV journalism in general and genre and thematic in particular, as well as the text content of news on television have undergone significant changes. The influence of technical progress and understanding of the needs of the audience caused by it is felt increasingly more. A modern TV viewer, having had the opportunity to get acquainted with the latest events via the Internet, becomes more demanding to the speed of information delivery, as he has the opportunity to learn the latest events online. But only 24-hour information TV channels that are not bound by strict broadcasting makeup can use live broadcasts from the scene of events constantly. Owing to TV broadcasters, prompt event reporting becomes available at any moment. Thus, with the rapid spread of the influence of the mass media sphere, a new type of human appears - homo informaticus, and culture reaches a new level, starting cooperation with the mass media (Popil, 2013, p. 364).

The American model of news reporting has a long history of formation and, taking into account the development of technological progress in the USA, has quickly become authoritative for news reporting in other countries too. It was synthesised with different models and traditions of local journalism and began to be used in many countries, mainly in the field of foreign broadcasting. 
At the same time, most researchers agree with the existence of an original model of news reporting in the USA. Scholars call this model: "neutral journalism" (Mykhailyn, 2011, p. 66; Moskalenko et al., 1999, p. 176), "North Atlantic Model” (Kvasnytsia, 2013, p. 32), “North Atlantic, or Liberal Model” (Hallin \& Manchini, 2008) and others. In our opinion, the aptest name is the guideline of American journalism "news, not views", which is reproduced by I. Mykhailyn (2011) - "news without views". From these names - "news without views" or "news without commentary" - the essence of the American model of news reporting becomes somewhat clear.

In US television discourse, the news is differentiated into "hard" and "soft" ones. The difference between these types of information is both in the subject of the described news and in the features of their presentation.

"Hard" information usually concerns government, economy, business, and so on. The factual series expands due to facts-causes, facts-consequences and is supplemented by cultural material at the level of vocabulary. The very first sentences answer a number of questions - "Who?", "What?", "Where?", "When?", By whom?", less often - "Why?". Speaking of "hard" information, we note that the main requirements for news of this kind are rapidity and accuracy. Therefore, "hard" news is quite highly rich in quantifiers, numerals - number, dates, etc. The use of such quantitative indicators requires the information richness peculiar to these texts.

In "hard" news, the author, paying attention on the importance of the result, often operates the facts based on "declining interest", starting with the most important. Thus, a structure known as an "overturned" or "inverted pyramid" is built (Korochenskii, 2006). The principle of the "inverted pyramid" implies that the most important information (the main message) is placed at the beginning of the news. Then, according to the principle of removal - less important information, details of the event.

In the "soft" version, the rapidity of information is reduced significantly, because, at the beginning of the news, it is not necessary to indicate when and where the event took place. Such information can hardly be called an emergency (breaking news). In the "soft" version, a moment of intrigue is often introduced. However, the compositional organisation of "soft" news is much more flexible than "hard" one (Cherkashina, 2018).

The methodology according to which D. Hallin and P. Manchini (2008) analyse the modern model of American news reporting, which includes such countries as Great Britain, the USA, Canada and Ireland, is based on four basic parameters-degrees:

- development of mass media determines the dominance of print or electronic media;

- political parallelism;

- development of journalistic professionalisation;

- state intervention in the activities of the mass media and the media system.

But although D. Hallin and P. Manchini (2008) unite the USA and some European countries in the "North Atlantic Model" (which is partially since, on the one hand, the USA borrowed a lot from Britain, on the other hand, recently 
the style of news has become more informal on British channels, which allows some British researchers to talk about tabloidisation, Americanisation (McNair, 2009), there are some differences between the form of news presentation due to various factors, among which I. Stepura (2014) singles out the historical one because in the European model of broadcasting, the state has dominated since the era of radio. The "public broadcasting" model means that there is a structure between the state and the broadcaster that is funded by taxes of citizens has an independent Governing Board (in the UK it is the BBC Trust) and/or a system of public supervisory boards. The American broadcasting model has been private from the very beginning. Independence is achieved here due to the existence of several large private television and radio broadcasting companies and numerous local stations cooperating with them which broadcast a national range of programmes (Stepura, 2014, p. 268). And the importance of the leading journalist, the so-called "anchor" (Anchorman, anchor), who often performs the role of editor-in-chief of the information service, is traditionally high (Stepura, 2014, p. 269). As a rule, he hosts a program of "world" or "evening" news (Calmer, 1970).

The educational and informative trend is traditionally strong on British TV. The presentation in the news is deliberate and is conducted on behalf of the elite, "London intellectuals". Public television in the USA is also educational. Thus, the cultural opportunities of education are realised, which are connected with the formation of the cultural life of a person (Andreiko, 2009, p. 18).

The British news has a strong ideological component - there are many Labour supporters there and less - Conservatives (Garnham, 1989). It should be noted that European countries, in general, are characterised by the broadcasting of traditional ideological doctrines in the programs: right-wing bourgeois, socialist, Christian and socialist, etc. (Garnham, 1989). And in the American news the following principles are distinguished: ethnocentrism and patriotism (focus on national news, the American nation is "central", countries, where American socio-political practices are inherited, are approved, internal difficulties and crises are understood as a consequence of abuse of power or incompetence of individual politicians and only later as a miscalculation of the central government), altruistic democracy (the state for a person; fight against corruption); human rights and legality (competition of heroes and evildoers, where heroes are always honest and dedicate themselves to the public good), responsible capitalism (fair competition, gender equality, reliance on small or traditional family businesses as a basis for prosperity, hidden criticism of monopolies, consumer organisations as a counterbalance to dictatorship of business); small-town pastoralism (rural and anti-industrial values, traditional values as the basis of morality) (Gans, 2004, pp. 45-47). That's why although the model of news presentation in the USA corresponds to the guidelines of American journalism "news not views", but even without commentary, due to the selection of news or some other conditions, the communicator influenced on the audience consciously or unconsciously. This principle of application of the American journalism model on television is criticised by B. Potiatynyk (2014). In his opinion, in the United States, the entertainment function in jour- 
nalism dominates instead of the primary function of objective information. At the same time, television information is misinformation, as a rule, it means it's irrelevant, fragmented, and superficial (p. 32). Another journalist, N. Davies (2011), author of the book Flat Earth News, on the example of work of numerous leading world mass media proves that information journalism avoids analysis, does not check facts, fragments reality and thus distorts a person's perception of the world and what happens in it (p. 152). However, the choice of topic, facts, style, language, headline, photo - all this is either an independent choice of a journalist or the choice of the editorial board of a particular mass media (Vaishenberh, 2019, p. 27).

It should be noted that a developed genre theory has never existed in US journalism. Since the concept of "type" is more common than "genre" there. This is probably connected with the fact that the form of news recedes into the background in the USA because the priority is given to the subject of the material. In the American mass media, one piece of news often contains statements by leading politicians, specialists, experts, etc. (Moskalenko et al., 1999, p. 176), and the description of the situation alternates with factual information. At the same time, they are all presented in a cultural context, which makes it possible to see the connection between an event and the large-scale problems of society. News notes often contain a micro interview element.

Ukrainian news reporting has many features in common with American. However, both models are not homogeneous, because they are constantly in dynamics, influenced by different, sometimes incompatible, factors. Each country has its own cultural, political, historical traditions, but the impact of world globalisation trends in the USA occurred much earlier than in Ukraine. Mass culture as a factor of mass media commercialisation changes not only the genre structure and its functions, but also the very essence of the journalistic paradigm. At the same time, the application of emotional techniques of cultural communication is based on the semiotic and mainly mythological code.

In terms of social sciences, the Ukrainian media model is genealogically post-Soviet. Therefore, according to the Hallin-Manchini scheme, it should be classified as "Mediterranean or Polarized Pluralist Model", which implies certain features. So, let's compare them with the American ones: low circulation of print mass media and the leading role of television in public opinion formation is similar, and the presence of the elite press is different. In the USA, the electronic mass media focuses on local news traditionally, is characterised by "internal pluralism", and in Ukraine, the focus is on policy coverage.

In our country, there is also a belated development of commercial media, a low degree of economic independence and weak professional development. News reporting is characterised by strong state intervention, which leads to periods of censorship ("temnyky" ("winterers") in 2004), "wild deregulation", that is privatisation television and radio broadcasting of Ukrainian. In the Ukrainian researcher O. Kvasnytsia's (2013) opinion, this characteristic should be supplemented with such a category as mediatisation of politics (p. 32) (use of media for the implementation of their goals by the state, government, parties, financial and industrial groups). 
In the USA, the local historical nature of the mass media has influenced the specifics of professional journalistic development (Hallin \& Manchini, 2008) and is traditionally neutral. The press is focused on reporting information, not on interpreting the facts. There is also a tradition of "objective journalism" that protects journalists from the dictates of owners and prevents the instrumentalisation of the media (although there is a relative decline in "objectivity" under the influence of commercialisation in the late $20^{\text {th }}$ century) (Hallin \& Manchini, 2008).

Thus, the degree of influence of politicians on the mass media is high in Ukraine, and journalism is focused on commentaries. US news reporting, on the contrary, is characterised by the early promotion of media freedom. Professional development in the USA is "non-institutionalised self-regulation" (Hallin \& Manchini, 2008) (unlike in Ukraine); slow democratisation with weak legal institutions.

At the same time, Ukrainian news reporting borrows and implements certain features of the American model, which, since the second half of the $20^{\text {th }}$ century, has become expansive in the world. "Among the main elements of this expansion are mass media commercialisation and journalistic professionalisation with the emphasis on the requirement of "neutrality" (Hallin \& Manchini, 2008). The genesis of the Ukrainian model of news reporting - through a series of stages (from print and radio to television and the Internet) - has added new qualities to it - a subsystem of culture that has signs of autonomy, closedness and generalisation. The USA is a classic country of commercial television. Television in the USA is privately owned, there is no state-owned television. Private commercial television is subject to strict market laws, the principle of competition, which encourages TV journalists to be in a creative search for new television forms constantly to attract viewers. Television has become a recognised leader in mass media. The commercialism of the American model, that is the ability of a viewer to pay, led television to the point that viewers are divided by interests. Everyone can watch that channel and TV programs in which he is interested in by purchasing the appropriate package of channels (Shcherbyna, 2013, p. 96). This approach dictates American television to concentrate on the individual interests of the audience, high mobility, focus on dynamic development and leads to the emergence of the marketing model for which the "minority" becomes the decisive factor. The success of television depends on money. According to A. Shorina, American television is an industry, a means of business. The commercial model of television, TV companies focuses on rapid profit, the capture of new markets, competition in the production of television programs (Shorina, 2008).

So, in the US news model, the market dominates, and there is a tradition of the requirement to restrict the state (Hallin \& Manchini, 2008). Today in Ukrainian media realities, a peculiar synthesis of elements of two models is formed: the Mediterranean and the American (North Atlantic). It indicates both the dynamics of changes and the formation of its own media system in Ukraine and the uncritical assimilation and artificial introduction of elements of foreign media systems. The Ukrainian model of news reporting developed from the Soviet tradition when it was considered that: "journalistic information can- 
not but explain events and facts, that is, it is such information that comments, interprets" (Pelt, 1980, p. 63). It should also be noted that the Ukrainian tradition of journalism in both the Soviet and post-Soviet periods was closely connected with sociopolitical journalism. Providing an evaluation of events and striving for moralising are integral features of news products, which theoretically blurs the boundaries between sociopolitical journalism and propaganda. Mass culture and postmodernist mass media discourse have become attributes of today's Ukrainian culture. At the same time, the entry of the news genre into a new phase of development is associated with the emergence of interactive tools that have provided the convergence of all types of news on the Internet. This allows qualifying their totality as a subsystem that acts as an object of influence of the culture of society and its subject at the same time. At the same time, the mass media is a channel that determines cultural priorities, a change in mentality, as well as a wide range of axiological values.

While the US commercial mass media is balanced by the presence of public television, the commercial mass media dominates in Ukraine. In this context, the implementation of the "objective journalism" model risks to distort reality and manipulate public opinion. Although today the traditional neutrality and objectivity of news in the USA are questioned because the opinion underlying the news report (even if a commentary is absent) can be ordered and paid for, as well as the service of the communication agency. And the absence of commentary can also contribute to this: the more emotional, negative, simpler a fact is, the more chances of its successful spread.

However, in the USA there is a certain balance between "hard" and "soft" news, and in Ukraine, in O. Kvasnytsia's (2013) opinion, there is a significant imbalance between them, when social relevance, the importance of information yields inferior to the attractiveness of news (p. 36).

Recently, in the USA, the question of the ratio of a fact and commentary in the structure of news has become one of the most hotly debated. The classic normative model of news dominates there, which assumes that the facts are underlain, and opinions should come from authoritative sources (experts) in a balanced way and not be posed as the facts by a journalist. "Facts speak for themselves" (Chernykh, 2017, p. 262) - the journalist's duty comes to providing information about them without giving an assessment. A journalist is an impartial informant who has neither a personal nor a civil position. The report at different stages of information retains the "news core", that is the stable components of the structure that make up the what-where-when formula (WWW). But the absence of at least one of the components of the structure causes the deformation of the semantic space of the media text (McNelly, 1959). Thus, both the content of the news and the information picture of the world are deformed in the recipient's mind. Thus, the question of whether a journalist has the right to evaluate has been raised in the theoretical discussions in the USA over the last decade regarding the illusiveness of the true unity of journalism (McQueel, 2013, p. 263).

There is a lot of evidence of manipulation of information journalism in the Ukrainian media space. The objective model is supplemented by such as: "pre- 
cision”, “interpretative”, “investigative”, “new journalism” (Kvasnytsia, 2013, pp. 36-37). At the same time, the American news system has largely changed Ukrainian journalistic standards. These are, first of all, such standards as a balance of opinions or positions, rapidity, separation of facts from commentaries, reliability, accuracy, completeness of presented facts, etc. Modern Ukrainian news is distinguished by interactivity and audience proactivity. The consumer becomes the initiator of the report more often, encouraging traditional producers of information to take into account his needs. The western influence is also felt in this, but it should be noted that the news model has undergone significant changes in the West as well. "The Internet has expanded the possibilities of personal control over the consumption of news but has not taken care of how to make a complete picture of these atomic particles" (Associated Press, 2008 , p. 3). The modern consumer of news has become radically different from several previous mostly passive generations. After all, the electronic version of the news differs from the paper or television ones significantly, including the regularity of information flow. At the same time, American researchers predict that such an information breakthrough will not mean the death of the press or television news in their classic form, as the need for analytics and sociopolitical journalism will not lose relevance in the world of chaotic news (Associated Press, 2008, p. 3).

Regarding the functioning of factual information in sociopolitical journalism and its ability to influence on the viewers or readers, we pay attention to the cultural and philosophical features of publicist work, which is a form of existence of public opinion as the core of mass, everyday consciousness (ontological aspect) and at the same time a form of mass self-consciousness and reflections (gnoseological aspect). The specificity of a publicist work is that analytically separated from reality, the fact of current life as a fragment of reality is transplanted into the author's concept of reality. Thus, the synthesis of the American news model and the traditional Ukrainian one combines the provision of factual material in analytical or publicist works.

Thus, we can claim that culture, updating its peripheral elements quite easily, shows a strong reaction of rejection when it comes to its core, rejecting elements that are alien to it. Therefore, we can talk about the manifestation of a "protective reaction" (in our case - alternative forms of reflection of the spiritual life of society in the news).

At the same time, after Ukraine gained independence, the authority of the mass media was initially based on their manifestation as a particular branch of power designed to protect democracy. It was assumed that the press would make the government policy and its decisions transparent by performing feedback function in society. But now the mass media works, first of all, as problem intensifier, replicating and imposing the interests of small groups and "their masters" on society. The scandals are fomented, the values and culture of the nation are "reformatted" destructively. Today, Ukrainian news channels depend not so much on the state as on their audience, owners, sponsors and advertisers (and the commercial interests of the owners and advertisers coincide with the attention of the audience only partially). 


\section{Conclusions}

Thus, the cultural dimension of news reporting means the presentation of a certain format of news of historical and collective experience of people, national values, dominating in a certain ethnocultural community and penetrating the life and way of family life of its representatives, which are passed from generation to generation and are inviolable in the consciousness of the nation.

For news reporting, it is necessary to take into account cultural experience, as culturally oriented media system influences on value and cultural orientations, their dynamics, as well as norms, ideas, positions, ideas that prevail in society and affect its adaptability. The important circumstance for the ideological vector of news reporting is the social interaction that dominates in society and the state, which is influenced by national culture.

It is proved that in Ukraine, the processes of westernisation in the sphere of culture affected the genre of news, and journalism itself moved away from the post-Soviet one. It has become closer to the Mediterranean Model, but there is also a significant influence of the American one. Ukrainian news of the infotainment genre is created according to the American principles of providing information, format and method of program contenting, and a presenter remains a key person. Only the topics of discussion differ. The key influence of the American model of news reporting on the Ukrainian media space is in its focus on the level of information needs, information market laws, information of production culture and consumption in the information society, as well as the increase of the popularity of chaotic hierarchy of reports, the tendency to the regularity of information flow, multimedia.

We also single out the directions of this influence: the striving to form a positive image of the country through foreign news broadcasting; the balance of "hard" and "soft" news, that is news where information prevails and those where the public interest is more important; the decrease of commentaries and increase of the number of facts; increase of balance of opinions.

Thus, with the spread of its influence, media culture reaches a new level in cooperation with the mass media. Mass culture and postmodern mass media discourse have also become attributes of today's Ukrainian culture. The entry of the news genre into a new phase of development allows qualifying them as a subsystem that is the object of influence of the culture of society, and as its subject. At the same time, the mass media is a channel that influences on cultural priorities and changes in mentality. And the genesis of Ukrainian news reporting as a subsystem of culture has added new qualities to it which have signs of autonomy, secrecy and generalisation.

\section{References}

Alieva, M. (2015). Sovremennye tendentcii i perspektivy razvitiia kruglosutochnoi novostnoi televizionnoi zhurnalistiki [Current trends and development prospects of round-theclock news television journalism]. AST [in Russian]. 
Andreiko, I. V. (2009). Osoblyvosti vplyvu osvity ta kultury na formuvannia osobystosti v konteksti suchasnykh realii hlobalizatsii [Features of the influence of education and culture on the formation of personality in the context of modern realities of globalisation]. Visnyk of National Technical University of Ukraine "Kyiv Polytechnic Institute". Philosophy. Psychology. Pedagogics, 3, 14-18 [in Ukrainian].

Associated Press. (2008). A New Model of News. Studying the Deep Structure of YoungAdult News Consumption. A Research Report from The Associated Press and the Context-Based Research Group. http://manuscritdepot.com/edition/documentspdf/newmodel.pdf [in English].

Bauman, Z. (2018). Tekuchaia sovremennost [Flowing modernity]. Piter [in Russian].

Calmer, N. (1970). The Anchorman. Doubleday [in English].

Cherkashina, A. A. (2018). Osobennosti novostnoi zhurnalistiki v pechatnykh SMI SShA. In Zhurnalistika i mediaobrazovanie $v$ XXI veke [Journalism and media education in the $21^{\text {st }}$ century], Proceedings of the International scientific-practical conference (pp. 93-95). Publishing House BelSU [in Russian].

Chernykh, A. (2017). Mir sovremennykh media [The world of modern media]. Territoriia budushchego [in Russian].

Davies, N. (2011). Novyny Plaskoi Zemli [Flat Earth News]. Tempora [in Ukrainian].

Dobrosklonskaia, T. G. (2005). Voprosy izucheniia mediatekstov: opyt issledovaniia sovremennoi angliiskoi mediarechi [Questions of studying media texts: the experience of studying modern English media speech]. Editorial URSS [in Russian].

Gans, H. (2004). Deciding What's News: A Study of CBS Evening News, NBC Nightly News, Newsweek and Time. Northwestern University Press [in English].

Garnham, N. (1989). Has Public Service Broadcasting Failed? In Life After the Broadcasting Bill, Proceedings of the $20^{\text {th }}$ University of Manchester Broadcasting Symposium. Manchester Monographs [in English].

Habermas, J. (2001). Moralnoe soznanie i kommunikativnoe deistvie [Moral Consciousness and Communicative Action] (D. V. Skliadnev, Trans.). Nauka [in Russian].

Hallin, D. S., \& Manchini, P. (2008). Suchasni mediasystemy: try modeli vidnosyn ZMI ta polityky [Modern media systems: three models of relations between the media and politics] (O. Nasyk, Trans.). Nauka [in Ukrainian].

Korochenskii, A. P. (2006). Otechestvennaia zhurnalistskaia nauka: mezhdu proshlym i budushchim [Domestic journalistic science: between past and future]. In Zhurnalistika i mediaobrazovanie $v$ XXI veke [Journalism and media education in the $21^{\text {st }}$ century], Proceedings of the International scientific-practical conference (pp. 12-18). Publishing House BelSU [in Russian].

Kvasnytsia, O. (2013). Publitsystyka vs novynna zhurnalistyka: motyvatsiia ta tsinnisni oriientyry [Journalism vs news reporting: motivation and values]. Visnyk of the Lviv University. Series: Journalism, 37, 30-45 [in Ukrainian].

McQuail, D. (2013). Zhurnalistika i obshchestvo [Journalism and society]. Media Mir [in Russian].

McNair, B. (2009). News and Journalism in the UK. Routledge [in English].

McNelly, J. T. (1959). Intermediary Communicators in the International Flow of News. Journalism Quarterly, 36(1), 23-26 [in English].

Moskalenko, A. Z. Huberskyi, L. V., \& Ivanov, V. F. (1999). Osnovy masovo-informatsiinoi diialnosti [Basics of mass information activity]. Taras Shevchenko National University of Kyiv [in Ukrainian]. 
Mykhailyn, I. (2011). Osnovy zhurnalistyky [Fundamentals of journalism]. Tsentr uchbovoi literatury [in Ukrainian].

Pelt, V.D. (1980). Informatciia $v$ gazete [Information in the newspaper]. Moscow Unviversity Press [in Russian].

Pocheptsov, G. (2014, October 12). Tri modeli postroeniia informatcionnykh operatcii. Detector media. https://ms.detector.media/manipulyatsii/post/11571/2014-10-12tri-modeli-postroeniya-informatsionnykh-operatsii/ [in Russian].

Popil, D. (2013). Suchasni ZMI v epokhu masovoi kultury ta postmodernu [Modern media in the era of mass culture and postmodernism]. TV and radio journalism, 12, 364-369 [in Ukrainian].

Potiatynyk, B. V. (2014). Media: kliuchi do rozuminnia [Media: keys to understanding]. PAIS [in Ukrainian].

Shcherbyna, Yu. (2013). Porivnialna kharakterystyka rozvazhalnykh shou na telekanalakh SShA ta Ukrainy [Comparative characteristics of entertainment shows on US and Ukrainian TV channels]. Scientific Notes of the Institute of Journalism, 51, 96-100 [in Ukrainian].

Shorina, A. Yu. (2008). Avtorske telebachennia: zhanrovi formy i riznovydy [Author's television: genre forms and varieties]. (Abstract of $\mathrm{PhD}$ Dissertation). Taras Shevchenko National University of Kyiv, Kyiv [in Ukrainian].

Stepura, I. (2014). Rol "iakirnykh" veduchykh novynnykh prohram na brytanskomu ta amerykanskomu telebachenni: sotsialno-psykholohichnyi analiz [The role of "anchor" leading news programs on British and American television: a sociopsychological analysis]. Language \& culture, 4(17), 268-272 [in Ukrainian].

Vaishenberh, Z. (2019). Novynna zhurnalistyka [News reporting]. Akademiia Ukrainskoi presy [in Ukrainian].

Zemlianova, L. M.(1999).Zarubezhnaia kommunikativistika v preddverii informatcionnogo obshchestva [Foreign communication in the run-up to the information society]. Moscow Unviversity Press [in Russian].

\title{
КУЛЬТУРОЛОГІЧНИЙ ВИМІР УКРАЇНСЬКОГО МЕДІАПРОСТОРУ У ВЗАЄМОДІЇ З АМЕРИКАНСЬКОЮ МОДЕЛЛЮ НОВИННОЇ ЖУРНАЛІСТИКИ
}

\author{
Красненко Олексій Леонідович
}

Аспірант, ORCID: 0000-0001-8398-8453, alexeykrasnenko@gmail.com, Київський національний університет культури і мистецтв, Київ, Україна

Мета статті - визначити вплив американської новинної журналістики на сучасний стан медіапростору в Україні в культурологічному аспекті. Методологія дослідження полягає у використанні культурологічного підходу, який включає аналіз змін українського суспільства і трансформацію новинної журналістики. 
Репортерські методи застосовувалися для сприйняття i iнтерпретації новин i новинної роботи журналіста. Аналітичний підхід допоміг виявити вплив американської моделі новинної журналістики на духовну культуру України. Метод моделювання був застосований для прогнозування майбутньої моделі української новинної журналістики в медіапросторі. Порівняльний аналіз використовувався при зіставленні американської та української моделей новинної журналістики. Наукова новизна полягає у тому, що вперше досліджено культурологічний аспект впливу американської моделі новинної журналістики на сучасний український медіапростір та спрогнозовано майбутню модель української новинної журналістики в медіапросторі.

Висновки. Доведено, що з поширенням свого впливу медіакультура виходить на новий рівень у співпраці із засобами масової інформації. Масова культура і постмодерністський дискурс ЗМІ стали атрибутами й сьогоденної української культури. Входження жанру новин у нову фазу розвитку дозволяє кваліфікувати їх і як підсистему, що виступає об’єктом впливу культури суспільства, і як її суб’єкт. При цьому 3MI $є$ каналом, що впливає на культурні пріоритети та зміни в менталітеті. А генезис української новинної журналістики як підсистеми культури додав їй нові якості, які мають ознаки автономізації, закритості і генералізації.

Ключові слова: ЗМІ; медіапростір; культура; культурологічний вплив; інформаційне суспільство; журналістика; новинна журналістика; американська модель.

\title{
КУЛЬТУРОЛОГИЧЕСКОЕ ИЗМЕРЕНИЕ УКРАИНСКОГО МЕДИАПРОСТРАНСТВА ВО ВЗАИМОДЕЙСТВИИ С АМЕРИКАНСКОЙ МОДЕЛЬЮ НОВОСТНОЙ ЖУРНАЛИСТИКИ
}

\author{
Красненко Алексей Леонидович
}

\section{Аспирант,}

ORCID: 0000-0001-8398-8453, alexeykrasnenko@gmail.com, Киевский национальный университет культуры и искусств, Киев, Украина

Цель статьи - определить влияние американской новостной журналистики на современное состояние медиапространства в Украине в культурологическом аспекте. Методология исследования заключается в использовании культурологического подхода, который включает анализ изменений украинского общества и трансформацию новостной журналистики. Репортерские методы применялись для восприятия и интерпретации новостей и новостной работы журналиста. Аналитический подход помог выявить влияние американской модели новостной журналистики на духовную культуру Украины. Метод моделирования был применен для прогнозирования будущей модели украинской новостной журналистики в медиапространстве. Сравнительный анализ использовался при сопоставлении американской и украинской моделей новостной журналистики. Научная новизна заключается в том, что впервые исследован культурологический аспект влияния американской модели новостной журналистики на современное украинское медиапространство и спрогнозирована 
будущая модель украинской новостной журналистики в медиапространстве. Выводы. Доказано, что с распространением своего влияния медиакультура выходит на новый уровень в сотрудничестве со средствами массовой информации. Массовая культура и постмодернистский дискурс СМИ стали атрибутами и сегодняшней украинской культуры. Вхождение жанра новостей в новую фазу развития позволяет квалифицировать их и как подсистему, которая выступает объектом воздействия культуры общества, и как ее субъект. При этом СМИ являются каналом, влияющим на культурные приоритеты и изменения в менталитете. А генезис украинской новостной журналистики как подсистемы культуры придал ей новые качества, которые имеют признаки автономизации, закрытости и генерализации.

Ключевые слова: СМИ; медиапространство; культура; культурологическое влияние; информационное общество; журналистика; новостная журналистика; американская модель. 